\title{
BARLEY $\alpha$-AMYLASE/SUBTILISIN INHIBITOR. I. ISOLATION AND CHARACTERIZATION
}

\author{
by \\ JOHN MUNDY1)2), IB SVENDSEN3) and JØRN HEJGAARD4)
}

\author{
1)Department of Biotechnology, Carlsberg Research Laboratory, \\ Gamle Carlsberg Vej 10, DK-2500 Copenhagen Valby \\ 2)Institute of Biochemical Genetics, Copenhagen University, \\ Øster Farimagsgade 2A, DK-1353 Copenhagen K. \\ 3)Department of Chemistry, Carlsberg Laboratory, \\ Gamle Carlsberg Vej 10, DK-2500 Copenhagen Valby \\ 4)Department of Biochemistry and Nutrition, \\ Technical University of Denmark, DK-2800 Lyngby
}

Keywords: Enzyme inhibition, subtilisin, $\alpha$-amylase isozymes, isoelectric focusing, amino acid composition

\begin{abstract}
A protein inhibitor of endogenous $x$-amylase 2 has been isolated from germinated barley by glycogen precipitation followed by cation-exchange chromatography. Preliminary kinetic analysis showed a mixed type mechanism of inhibition with an apparent $\mathrm{Ki}$ of $4 \times 10^{-8} \mathrm{M}$. The inhibitor formed well-defined complexes with barley malt $\mathrm{x}$ amylase 2 and co-purified with the $\alpha$-amylase by cycloheptaamylose affinity chromatography of glycogen precipitates. The inhibitor was inactive towards $x$-amylases from sorghum malt, hog pancreas, Aspergillus oryzae, and Bacillus subtilis. The amino acid composition and molecular weight near 21,000 were found to be the same as those of both "band-2 protein" previously identified in preparations of barley malt $x$-amylase and a specific subtilisin inhibitor from barley. Inhibition experiments confirmed that the malt $x$-amylase inhibitor is a strong inhibitor of subtilisin Carlsberg. Measurements of $x$-amylase activity in the presence of equimolar amounts of inhibitor and subtilisin showed that the inhibitor is "double headed". The inhibitory activity towards $x$-amylase was lost after treatment of the inhibjtor at $70^{\circ} \mathrm{C}$ for $15 \mathrm{~min}$. Isoelectric focusing patterns confirmed that the partially heat-labile, basic $x$-amylase isozymes $(\mathrm{pI}=6.6$ ) of barley malt are complexes of $x$-amylase $2(\mathrm{pI}=6.2)$ and the inhibitor $(\mathrm{pI}=7.2)$. Evidence is presented to suggest that proteins with properties similas to those of the barley inhibitor are present in other cereals including wheat and rye. Possible in vivo functions and some practical aspects of the barley inhibitor are discussed.
\end{abstract}

Abbreviations: $\mathrm{ATEE}=$ acetyl-tyrosine ethyl ester; $\mathrm{CHpA}=$ cycloheptaamylose; $1 \mathrm{EF}=$ isoelectric focusing; $\mathrm{PAGE}=$ polyacrylamide gel electrophoresis; SDS = sodium dodecylsulphate; TLC = thin layer chromatography. 


\section{INTRODUCTION}

Multiple molecular forms of $\alpha$-amylase in barley malt extracts have been studied using isoelectric focusing $(3,10)$. This technique reveals three major forms of $\alpha$-amylase, here named $\alpha$ amylases 1, 2, and 3. The same enzyme forms were called $\alpha$-amylase I, II, and III by MACGREGOR and BALLANCE (10). BROWN and JACOBSEN (3) have recently established the genetic basis of $\alpha$-amylase 1 and $\alpha$-amylase 2 , called $\alpha$-amylase 2 and 1 respectively by these authors. In contrast, the $\alpha$-amylase 3 form is partially heat-labile and is almost completely converted into $\alpha$-amylase 2 by treating malt extracts at $70{ }^{\circ} \mathrm{C}$ for $15 \mathrm{~min}$ at pH 5.5 (10). Recently, Rodaway (14) described the co-purification with barley $a$-amylase of a protein with a monomer molecular weight of 21,500 which was called band- 2 protein.

The present study shows that $a$-amylase 3 is a complex of $\alpha$-amylase 2 and band- 2 protein which was purified and demonstrated to be an $\alpha$ amylase inhibitor. Of equal interest is the finding that this $\alpha$-amylase inhibitor has previously been isolated from barley and characterized as an inhibitor of subtilisin by YoshIKaWA et al. (17). The $\mathrm{N}$-terminal sequence identity of these two proteins and their homology with inhibitors of the soybean Kunitz type is described by HeJGaARD et al.(6). A bifunctional inhibitor of animal $\alpha$ amylases and trypsin has recently been characterized from Indian finger millet by SHIVARAJ and Pattabiraman (15). This millet inhibitor and the barley endogenous $\alpha$-amylase 2 /subtilisin inhibitor described here differ significantly, however, in molecular weights and specificities of inhibition.

\section{MATERIALS AND METHODS}

\subsection{Plant material}

Commercial green and kilned barley malts (Hordeum vulgare, cv. Gula, a common Danish malting variety) were obtained from the Carlsberg Maltings, Copenhagen. Seeds of wheat (Triticum vulgare cv. Solid), rye (Secale cereale cv. Petkus) and sorghum (Sorghum bicolor, cv. Dabar) were malted in a rotating laboratory malter. The seeds were steeped for 24 hours followed by a five day germination at $16{ }^{\circ} \mathrm{C}$ for wheat and rye and at $25{ }^{\circ} \mathrm{C}$ for sorghum. All malts were lyophilized and stored at $-20^{\circ} \mathrm{C}$.

\subsection{Chemicals}

Epoxy-activated Sepharose 6B, Sephadex G

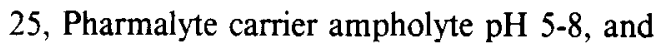
low molecular weight electrophoresis calibration proteins were obtained from Pharmacia, Uppsala, Sweden. CM-cellulose type CM-52 was from Whatman, Maidstone, England. TLC silica gel 60 aluminum sheets, soluble starch and neocuproin hydrochloride were obtained from Merck, Darmstadt, Germany. $\beta$-cycloheptaamylose $(\mathrm{CHpA})$, ovalbumin, bovine pancreas ribonuclease, Aspergillus oryzae $\boldsymbol{\alpha}$-amylase, Bacillus subtilis $\alpha$-amylase and ATEE were from Sigma, St. Louis, U.S.A. Hog pancreas $\alpha$ amylase was from Boehringer Mannheim GmbH, Mannheim, W. Germany. Subtilisin Carlsberg was a gift of Novo Industries, Copenhagen, Denmark. This crystallized and freeze-dried product was gel filtrated on Sephadex $\mathrm{G} 25$ at $4^{\circ} \mathrm{C}$ immediately before use in order to remove autolysis products. The $\mathrm{CHpA}$ Sepharose 6B affinity gel was prepared according to Silvanovitch and Hill (16).

\subsection{Electrophoretic techniques}

Isoelectric focusing in polyacrylamide slab gel (IEF-PAGE), pH 5-8, and detection of $\alpha$-amylase activity was performed as previously described (12). Isoelectric focusing in gel rods and staining for protease activity to visualize subtilisin inhibitory activity was performed after HejgaARd (5). Sodium dodecyl-sulphate polyacrylamide gel electrophoresis (SDS-PAGE) was performed after Neville (13).

\subsection{Isolation of the inhibitor and $\alpha$-amylase 2}

Extraction and glycogen precipitation of barley, sorghum, wheat and rye malt amylases, chromatography of barley malt $\alpha$-amylases as well as chromatography of ion-exchange purified barley malt $\alpha$-amylase inhibitor on $\mathrm{CHpA}$ Sepharose $6 \mathrm{~B}$ were performed as described by SILVANOVITCH and HILL (16). Separation of $\alpha$-amylase 2 and the $\alpha$-amylase inhibitor from barley malt was accomplished by chromatography of a redissolved glycogen precipitate on carboxymethyl-cellulose (Whatman CM-52 microgranular). This ion ex- 
change was performed essentially as described by MACGregor et al. (11) except that a slight $\mathrm{pH}$ gradient was also employed (see Figure 2, legend).

\subsection{Amino acid analyses}

Amino acid analyses were made in duplicate. Samples $(40 \mu \mathrm{g})$ were hydrolyzed for 24,48 and 72 hours in $5.7 \mathrm{M}-\mathrm{HCl}$ in evacuated and sealed tubes. Values for serine and threonine were extrapolated to zero hours. Cystein was determined as cysteic acid after Hirs (7). All hydrolysates were analyzed on a Durrum D-500 amino acid analyzer.

\subsection{Measurement of subtilisin activity and inhibition}

The activity and inhibition of subtilisin Carlsberg were measured in $10 \mathrm{~mm}-\mathrm{KCl}$ in a pH-stat at room temperature with $10 \mathrm{~mm}$-ATEE as substrate. The enzyme was incubated with various amounts of the inhibitor for $10 \mathrm{~min}$. Aliquots were then added to the substrate and the rate of hydrolysis measured by the uptake of $10 \mathrm{~mm}$ $\mathrm{NaOH}$ as a function of time.

\subsection{Measurement of $\alpha$-amylase activity and inhibition}

The $\alpha$-amylase 2 and amylase inhibitor purified by ion-exchange chromatography (section 2.4) were used for the inhibition measurements. In a standard assay, $0.66 \mu \mathrm{g} \alpha$-amylase 2 was preincubated with different amounts of the inhibitor in $50 \mu \mathrm{l}$ of $20 \mathrm{~mm}-\mathrm{Na}$-phosphate, $\mathrm{pH} 6.0$, $20 \mathrm{~mm}-\mathrm{NaCl}, 1 \mathrm{~mm}-\mathrm{CaCl}_{2}$ in microfuge tubes at $37^{\circ} \mathrm{C}$ for $20 \mathrm{~min} .250 \mu \mathrm{l}$ of $1 \%$ soluble starch in the same buffer was then added and the solution mixed by drawing it into a pipette 3 times. This assay solution was incubated at $37^{\circ} \mathrm{C}$ for $10 \mathrm{~min}$ and duplicate $50 \mu \mathrm{l}$ aliquots were then analyzed for reducing sugars using the neocuproin reagent after DYGERT et al. (4). The values obtained (glucose equivalents) were used to generate the plots shown in Figures $5 \mathrm{~A}$ and $\mathrm{B}$ and Dixon plots (I/v vs. I, not shown).

Four different concentrations of starch (9.6, $6.6,5.0$, and $4.0 \mathrm{mg} \cdot \mathrm{ml}^{-1}$ ) were used with three different amounts of inhibitor $(0.33,0.66$, and $1.33 \mu \mathrm{g}$ ) for plots of $1 / \mathrm{v}$ vs. $1 / \mathrm{s}$ after LiNEWEAVER and BURK.
The effect of subtilisin on the inhibition of $\alpha$ amylase was measured by preincubating subtilisin and the inhibitor $(0.25$ or 1 mole subtilisin per mole inhibitor) for $10 \mathrm{~min}$. $\alpha$-Amylase 2 was then added and after a further preincubation of $20 \mathrm{~min}$, the assay was performed as described above.

Starch digests for thin layer chromatography after KolLER and NEUKON (9) were made by incubating $\alpha$-amylase with the inhibitor or control proteins (ribonuclease or ovalbumin) with $100 \mu 1$ $1 \%$ starch in distilled water, because buffer was found to disturb the TLC solvent flow.

\section{RESULTS AND DISCUSSION}

\subsection{Purification of a MW 21,000 protein from barley malt}

The starting material for the purification was a glycogen precipitate of an extract of barley malt (16). SDS-PAGE of the glycogen precipitate showed substantial amounts of a protein of molecular weight 20,000-22,000 (Figure 1, lane 1) in accordance with the results of RODAWAY (14). Glycogen did not precipitate the MW 21,000 protein from extracts of barley, although this protein is present in large amounts in barley (17).

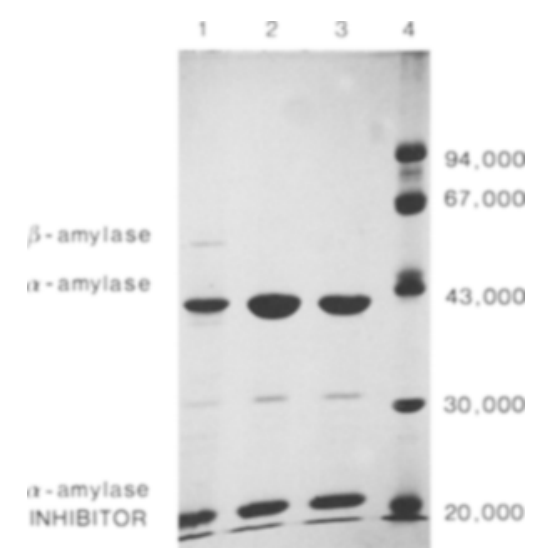

Figure 1. Proteins in barley malt amylase preparations.

Samples (aproximately $40 \mu \mathrm{g}$ ) were compared by SDS-PAGE in a $12 \%$ gel. Lanes: 1 , barley glycogen precipitate; 2 , barley affinity bound fraction from the CHpA Sepharose column; 3, high-salt fraction (0.1$0.3 \mathrm{M}-\mathrm{NaCl}$ ) from $\mathrm{CM}$-cellulose chromatography. The molecular size standards are (from top to bottom): rabbit muscle phosphorylase $B$, bovine serum albumin, egg white ovalbumin, bovine erythrocyte carbonic anhydrase, soybean trypsin inhibitor. 


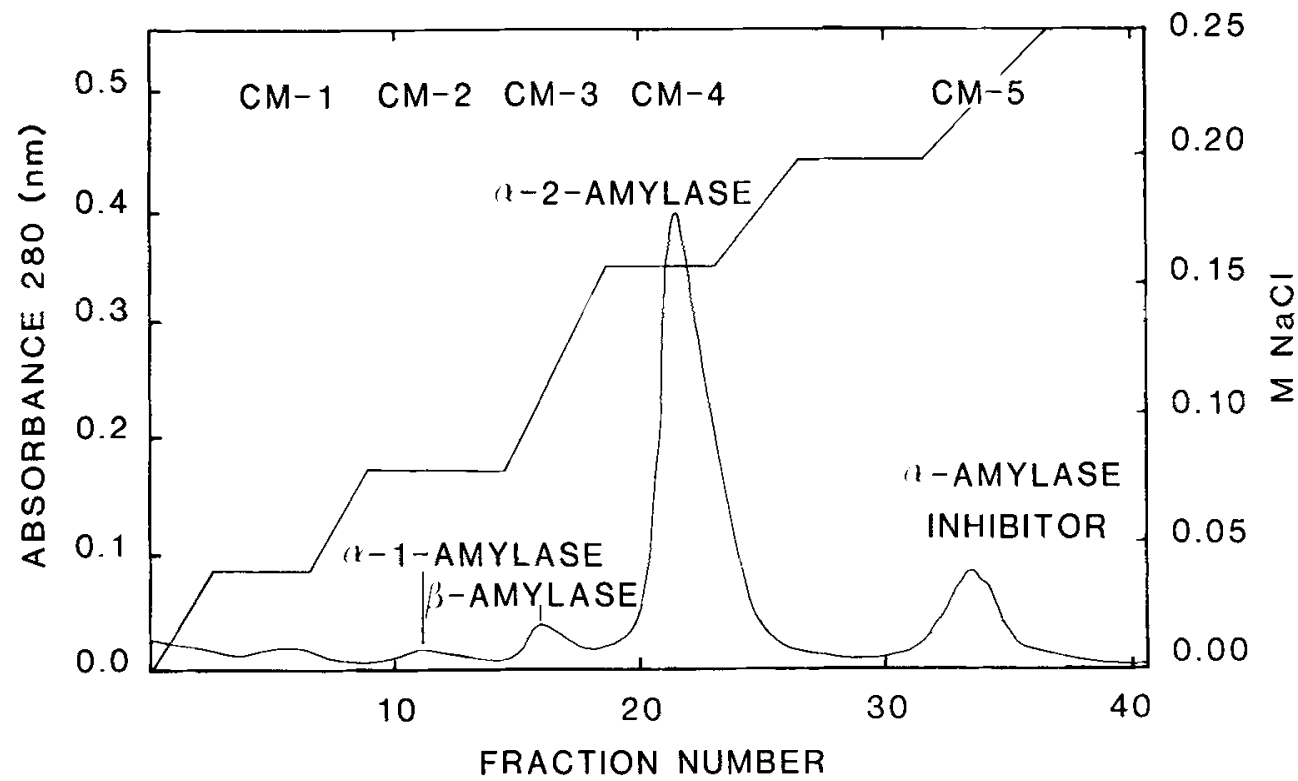

Figure 2. CM-cellulose chromatography of glycogen precipitate of barley malt.

The glycogen precipitate (approximately $25 \mathrm{mg}$ protein) dissolved in $10 \mathrm{ml} 0.02 \mathrm{M}-\mathrm{Na}$-Acetate, pH 4.75 , ImM$\mathrm{CaCl}_{2}$, and $1 \mathrm{mM}-\beta$-mercaptoethanol was loaded onto a $2.5 \times 5 \mathrm{~cm}$ column of Whatman CM-52 microgranular previously equilibrated in the same buffer. Elution with $300 \mathrm{ml}$ start buffer versus $300 \mathrm{ml}$ of the same buffer at $\mathrm{pH}$ 5.1 with $0.2 \mathrm{M}-\mathrm{NaCl}$ was performed using an adapted gradient formed by an LKB 11300 Ultrograd Gradient Mixer. The flow rate was $35 \mathrm{ml} \cdot \mathrm{hr}^{-1}$ and $17.5 \mathrm{ml}$ fractions were collected. The following fractions were pooled: CM-1, fractions 5-9; CM-2, fractions 11-15; CM-3, fractions 16-18; CM-4, fractions 20-27; CM-5, fractions 31-36.

The MW 21,000 protein was found to co-purify with barley $\alpha$-amylase by affinity chromatography of the glycogen precipitate on CHpASepharose 6B (lane 2). The MW 21,000 protein was also co-purified with barley $\alpha$-amylase 2 by batch ion exchange chromatography of the affinity bound fraction from the $\mathrm{CHpA}$ column on CM-cellulose (lane 3). This batch ion exchange procedure has been used at the Department of Biotechnology to separate barley $\alpha$-amylase 1 from $\alpha$-amylase 2 due to the different isoelectric points of these $\alpha$-amylase isozymes. It was, however, found that the MW 21,000 protein and the amylases could be separated from each other by chromatography of the glycogen precipitate on CM-cellulose using a combined salt and slight pH gradient (Figure 2). SDS-PAGE (Figure 3) demonstrated the almost complete separation of $\alpha$-amylase 1 (fraction CM-2), $\beta$-amylase (CM-3), $\alpha$-amylase $2(\mathrm{CM}-4)$, and the MW 21,000 protein (CM-5). These fractions, pooled according to the legend of Figure 2, were used in the subsequent experiments. The yield of protein was approx-

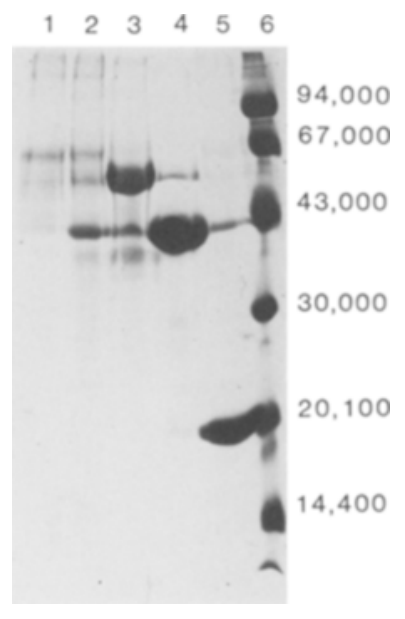

Figure 3. Proteins in pooled fractions from CM-cellulose chromatography.

Samples (approximately $15 \mu \mathrm{g}$ ) were compared by SDS-PAGE in a $15 \%$ gel. Lanes $1-5$ are column fractions CM-1 to CM-5, respectively (Figure 2). Lane 6 is a molecular size standard mixture as in Figure 1 plus bovine milk $x$-lactalbumin (MW 14,400). 
imately $10.5 \mathrm{mg} \alpha$-amylase 2 and $2.75 \mathrm{mg} \alpha$ amylase inhibitor from $125 \mathrm{~g}$ freeze-dried malt.

Purified $\alpha$-amylase 2 (CM-4) was released from the CHpA-affinity column with 8 $\mathrm{mg} \cdot \mathrm{ml}^{-1} \mathrm{CHpA}$ in elution buffer. In contrast, preparations of the MW 21,000 protein free of $\alpha$ amylase (CM-5) were found not to bind to the CHpA-affinity column except in extremely small amounts $\left(30 \mu \mathrm{g} \cdot \mathrm{ml}^{-1}\right)$ which required high salt concentrations for their release. During affinity chromatography of glycogen precipitates, however, much larger amounts of the MW 21,000 protein were co-eluted with $\alpha$-amylase 2 by $8 \mathrm{mg} \cdot \mathrm{ml}^{-1} \mathrm{CHpA}$ in elution buffer. Purification of barley $\alpha$-amylase by this $\mathrm{CHpA}$-affinity technique should therefore not be used as the only chromatographic step in the purification of $\alpha$-amylase from barley malt.

\subsection{Amino acid composition of the MW 21,000 protein}

The amino acid composition of the barley malt MW 21,000 protein is given in Table I along with values from the characterization of a specific subtilisin inhibitor by YoSHIKAwa et al. (17) and of band-2 protein by RoDAway (14). Apart from minor differences, the compositions of the three proteins appear to be the same. This similarity prompted us to test the ability of the MW 21,000 protein to inhibit subtilisin.

\subsection{The effect of the MW 21,000 protein on subtilisin activity}

Inhibition experiments showed that a 2 or 4 fold molar excess of the MW 21,000 protein over subtilisin completely abolished the hydrolysis of the substrate ATEE, while $88 \%$ inhibition was obtained at a 1:1 molar ratio of enzyme to inhibitor. This is similar to the results of YosHIKAWA et al. (17) who found approximately $75 \%$ and more than $95 \%$ inhibition of subtilisin BPN' and subtilisin amylosaccharitics, respectively, when these enzymes were incubated with equimolar amounts of the inhibitor.

\subsection{Inhibition of $\alpha$-amylases}

The effect of incubating $\alpha$-amylase 2 with the MW 21,000 protein on the amount of hydrolysis products released from soluble starch is shown in Figure 4 (lanes 2, 3 and 4). The inhibitor could be
Table I.

Comparison of the amino acid composition of the barley malt $\alpha$-amylase/subtilisin inhibitor with that of the barley subtilisin inhibitor (17) and band-2 protein (14). The compositions are adjusted for a protein molecular weight of 21,000 .

\begin{tabular}{|c|c|c|c|}
\hline & $\begin{array}{l}\text { Barley malt } \\
x \text {-amylase } \\
\text { inhibitor }\end{array}$ & $\begin{array}{c}\text { Barley } \\
\text { subtilisin } \\
\text { inhibitor } 1\end{array}$ & $\begin{array}{l}\text { Barley malt } \\
\text { band- } 2 \\
\text { protein } 2\end{array}$ \\
\hline Asp & 17.7 & 18.5 & 19.3 \\
\hline Thr & 8.9 & 8.7 & 9.4 \\
\hline Ser & 10.1 & 10.9 & 11.7 \\
\hline Glu & 16.1 & 13.7 & 14.5 \\
\hline Pro & 15.7 & 15.9 & 16.4 \\
\hline Met & 2.3 & 2.2 & 1.7 \\
\hline Gly & 21.2 & 19.0 & 21.3 \\
\hline Ala & 17.2 & 16.3 & 17.1 \\
\hline Val & 13.4 & 14.3 & 10.5 \\
\hline Ile & 7.2 & 7.9 & 5.6 \\
\hline Leu & 12.5 & 10.8 & 12.8 \\
\hline Tyr & 6.7 & 7.3 & 8.1 \\
\hline Phe & 7.3 & 7.0 & 8.1 \\
\hline His & 9.6 & 9.8 & 10.8 \\
\hline Lys & 6.9 & 6.3 & 8.2 \\
\hline Arg & 12.2 & 13.8 & 13.1 \\
\hline $1 / 2$ Cys & 4.3 & 4.4 & $4.0^{3}$ \\
\hline Trp & - & 2.9 & $3.0^{3}$ \\
\hline Total & 192.3 & 189.4 & 195.6 \\
\hline \multicolumn{4}{|c|}{$\begin{array}{l}1 \text { molecular weight given as } 19,500(17) \\
2 \text { molecular weight given as a dimer of } 43,000 \text { (mono- } \\
\text { mer weight } 21,500)(14) \\
3 \text { values calculated from (17) }\end{array}$} \\
\hline
\end{tabular}

inactivated by heat treatment at $70{ }^{\circ} \mathrm{C}$ for 20 minutes (lane 5). Incubating $\alpha$-amylase 2 with control proteins (ovalbumin and ribonuclease) did not affect the hydrolysis (lanes 7 and 9). This suggests that the inhibitory action of the MW 21,000 protein is due to a specific interaction with $\alpha$-amylase 2 .

The result of quantitative measurements of the decrease in the activity of barley malt $\alpha$-amylase 2 in the presence of increasing amounts of the purified MW 21,000 protein are shown in Figure $5 \mathrm{~A}$. This experiment shows that the inhibitor is both in a free and a combined state in that the curve approximates two straight lines. The binding between $\alpha$-amylase and the inhibitor therefore does not exhibit the very tight bind- 


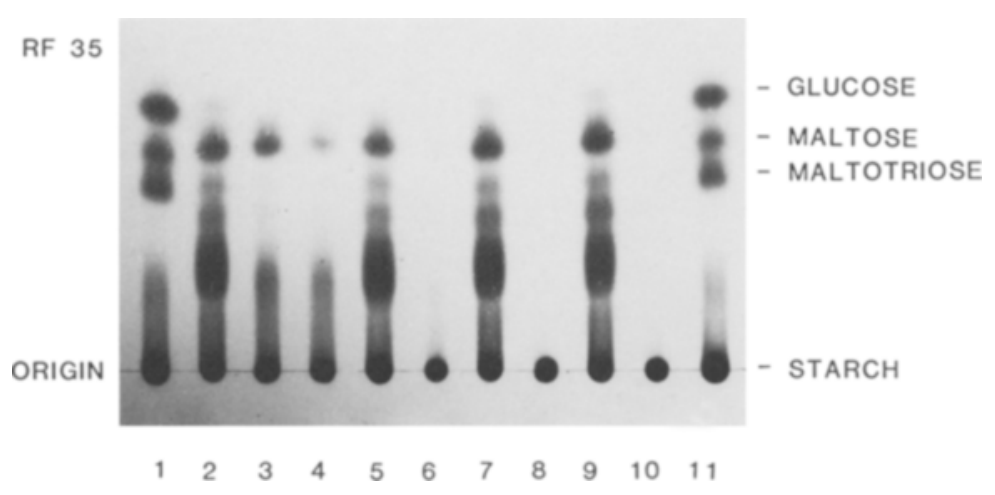

Figure 4. Effect of the inhibitor on hydrolysis of soluble starch by $\alpha$-amylase 2 .

$0.33 \mu \mathrm{g} \alpha$-amylase 2 was incubated with the inhibitor or control proteins for $20 \mathrm{~min}$ at $37^{\circ} \mathrm{C}$ in microfuge tubes prior to the addition of $100 \mu \mathrm{l}$ of a $1 \%$ soluble starch solution. The reaction was stopped by placing the tubes in a boiling water bath for $3 \mathrm{~min} .20 \mu \mathrm{l}$ aliquots were analyzed by TLC after KOLLER and NEUKON (9).

Lanes 1 and 11, $20 \mu \mathrm{g}$ glucose, maltose, maltotriose and soluble starch standards. Lanes $2-5,2) 1 \mu \mathrm{g} \alpha$-amylase 2 alone, 3) with $2 \mu \mathrm{g}, 4) 10 \mu \mathrm{g}$, and 5) with $2 \mu \mathrm{g}$ separately heat treated inhibitor. Lane 6, $2 \mu \mathrm{g}$ inhibitor alone. Lanes 7 and $9, x$-amylase 2 with $2 \mu \mathrm{g}$ ovalbumin and ribonuclease, respectively. Lanes 8 and 10 , ovalbumin and ribonuclease, respectively.
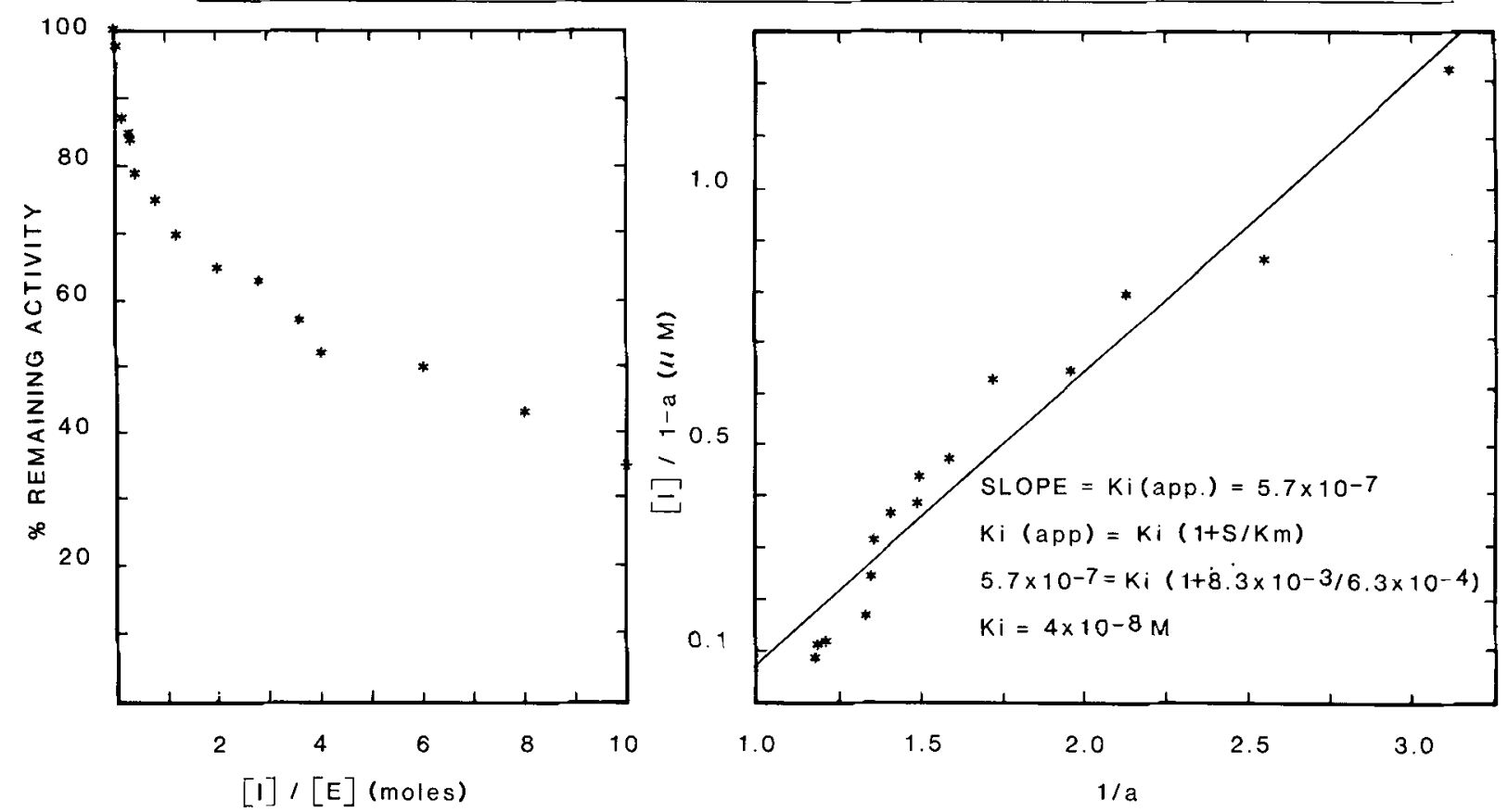

Figure $5 \mathrm{~A}$. Inhibition of $x$-amylase 2 .

Plot of percent remaining $\alpha$-amylase activity versus mole ratio of inhibitor to barley $\alpha$-amylase 2 . Assay conditions were as described in section 2.7 .

Figure 5 B. Determination of the inhibitor constant (Ki).

The data plotted in Figure $5 \mathrm{~A}$ were used to generate this curve whose slope is defined as the apparent inhibitor constant (Ki app). a = relative enzyme activity in the presence of inhibitor. $\mathrm{S}=$ substrate concentration in the assay $\left(8.3 \times 10^{-3} \mathrm{~g}\right.$ starch $\left.\cdot \mathrm{ml}-1\right) . \mathrm{Km}=$ Michaelis constant for $x$-amylase 2 determined previously $\left(6.3 \times 10^{-4} \mathrm{~g} \mathrm{starch} \cdot \mathrm{ml}-1\right.$, see Mundy, 12). Ki was determined from Ki app by the method of BIETH (1) as shown in the figure. 
ing characteristic of many protease/protein inhibitor interactions. The inhibition was determined to be non-stoichiometric as defined by BIETH (1) in his analysis of methods for determining the inhibition constants $(\mathrm{Ki})$ of protein inhibitors of proteases. Experiments measuring the time dependence of substrate hydrolysis after addition of an aliquot of substrate showed an exponential release of product during the first three minutes of the assay (results not shown). This result indicates that the enzyme-inhibitor complex formed during the preincubation is dissociated by substrate. Ki was therefore determined according to the equations presented by BIETH (1) (Figure 5 B).

Dixon (l/v vs. I) and Lineweaver-Burke ( $1 / \mathrm{v}$ vs. $1 / \mathrm{s})$ plots derived from experiments using four different substrate concentrations and three different concentrations of inhibitor showed a pattern of mixed inhibition of $\alpha$-amylase 2 with an apparent $\mathrm{Ki}=7 \times 10^{-8} \mathrm{M}$. Further evidence for a partially noncompetitive mechanism for the barley inhibitor comes from two other experiments. The formation of an enzyme-inhibitorsubstrate complex is shown by the copurification of the inhibitor with $a$-amylase 2 during glycogen precipitation and $\mathrm{CHpA}$-affinity chromatography (assuming that $\mathrm{CHpA}$ is an active site inhibitor). That the inhibitor also binds to the enzyme in the absence of substrate is shown by the occurence of inhibitor-enzyme complexes during isoelectric focusing (see section 3.5).

Other experiments showed that the inhibition of $\alpha$-amylase is not affected by the presence of equimolar amounts of subtilisin in the assay mixture. This result indicates that the inhibitor is "double-headed" and contains separate sites directed against $\alpha$-amylase and subtilisin.

The order of $\mathrm{Ki}\left(10^{-7}-10^{-8} \mathrm{M}\right)$ for the inhibition of $\alpha$-amylase by this bifunctional barley inhibitor is similar to those reported for several wheat $\alpha$-amylase inhibitors. Although these wheat proteins are generally considered to be uncompetitive inhibitors of $\alpha$-amylase, considerable uncertainty exists in the literature regarding their actual kinetic mechanism and the assay conditions required to measure it. In these studies, deviations in inhibition data from classical models were explained by a binding between the inhibitor and the polysaccharide substrate or by the possibility that the inhibition reaction is much slower than starch hydrolysis (2). The wheat $\alpha$-amylase inhibitors, however, only inactivate animal $\alpha$-amylases, including enzymes of mammals, avian species, and some grain infesting insects, but not the $\alpha$-amylases of malted wheat. The barley inhibitor described here was found to be inactive towards $\alpha$-amylases from hog pancreas, Aspergillus oryzae and Bacillus subtilis. The inhibitor was also inactive towards sorghum malt $\alpha$-amylase, purified according to Mundy (12), and was inactive towards barley malt $\beta$-amylase purified by ion-exchange chromatography (fraction CM-3, Figure 2). The amylase of Tenebrio molitor (yellow meal worm), which is generally used in assays of the wheat inhibitors because it is inactivated by all molecular forms of the wheat $\alpha$-amylase inhibitors, has not been tested with the barley inhibitor.

\subsection{Effect of the inhibitor on amylase zymograms}

Isoelectric focusing experiments were performed to determine whether the inhibitor forms an identifiable complex with purified $\alpha$ amylase and whether this complex occurs in amylase zymograms of barley malt extracts. Electrophoresis of mixtures of purified $\alpha$ amylase 2 and inhibitor clearly shows such a complex with an intermediate isoelectric point (Figure $6 \mathrm{~A}$ ). Zymogram staining of these gels shows that the inhibitor-enzyme complex has both $\alpha$-amylase activity and subtilisin inhibitory activity (Figure $6 \mathrm{~B}$ ). This result again indicates that the inhibitor is double-headed.

These results suggested that the most basic barley malt $\alpha$-amylase form, called $\alpha$-amylase III by MACGREGOR and BALLANCE (10), might in fact be a complex between $\alpha$-amylase 2 and the inhibitor. Isoelectric focusing in flat bed gels of green and kilned malt extracts and of the purified enzyme and mixtures of the enzyme and inhibitor clearly show that this is the case (Figure 7 ). This complex ( $\alpha$-amylase 3 ) furthermore appears to be partially heat labile, a result in agreement with the findings of MACGREGOR and BALLANCE (10). 


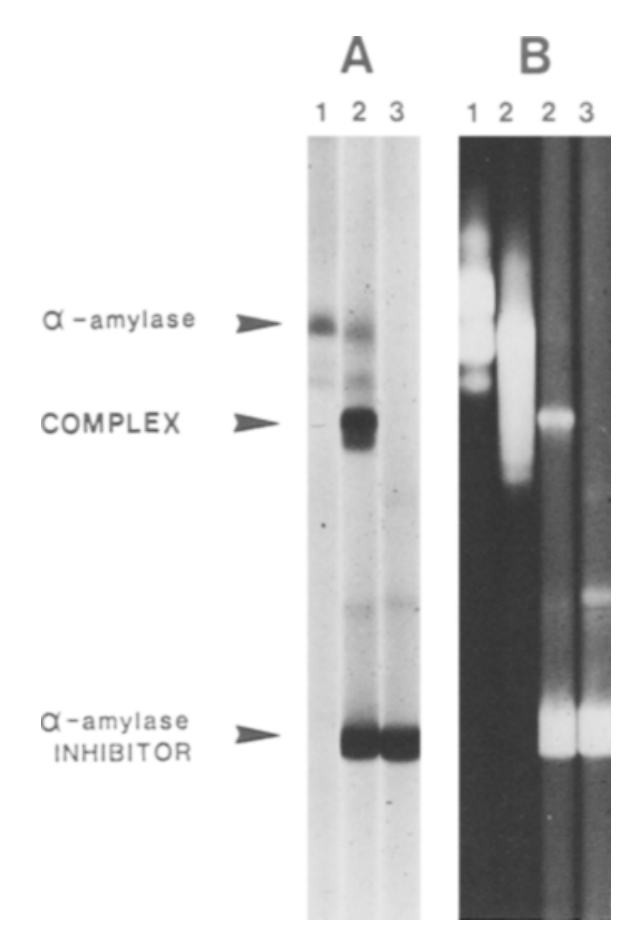

Figure 6. Complex formation between the inhibitor and $\alpha$-amylase 2 .

Interactions between the purified inhibitor and $\alpha$ amylase 2 (Fractions CM-4 \& 5, Figure 2) were studied by isoelectric focusing in polyacrylamide gel rods after Hejgaard (5). A: gels 1-3 were stained for protein with Coomassie Blue after focusing 1) $2 \mu g \alpha$-amylase 2,3 ) 5 $\mu \mathrm{g}$ inhibitor, and 2) a mixture of these two samples. B: after focusing the same samples, gels 1 and 2 (left) were stained for amylase activity and gels 2 and 3 (right) were stained for protease activity to visualize subtilisin inhibitory activity.

\subsection{Possible in vivo functions of the inhibitor and some practical aspects}

The molecular weight and amino acid composition of the barley $\alpha$-amylase/subtilisin inhibitor are different from those of the $(0.19)$ and $(0.28)$ wheat $\alpha$-amylase inhibitors which all have monomer molecular weights near 12,000 (see BUONOCORE (2) for a review). The molecular weight and specificity of the barley $\alpha$-amylase/ subtilisin inhibitor also differs significantly from those of the bifunctional inhibitor of animal $\alpha$ amylase and trypsin characterized by SHIVARAJ and Pattabiraman (15). These two bifunctional proteins thus presumably represent two different families of plant hydrolase inhibitors. It has long been known that the wheat albumin inhibitors of animal $\alpha$-amylases are located in the endosperm and are associated with starch granules. These inhibitors are apparently unable to inhibit endogenous $\alpha$-amylase and have therefore generally been assigned protective rather than regulatory roles during seed development. In contrast, the inhibitor from barley described here may have both a regulatory function by inhibiting endogenous $\alpha$-amylase and a protective function by inhibiting a microbial protease.

The barley subtilisin inhibitor was present in relatively large amounts (about $1.4 \mathrm{mg} \cdot \mathrm{g}^{-1}$ grain) in grain of the cultivar used by YosHIKAWA et al. (17) for its purification. In the study by RoDAwaY (14), where de-embryonated seeds were incubated with labelled amino acids after inhibition for 3 days, most radioactivity was recovered in de novo synthesized a-amylase, while the band- 2 protein (the $\alpha$-amylase/subtilisin inhibitor) was not labelled noticeably. These results show that the barley $\alpha$-amylase/subtilisin inhibitor is an endosperm protein not actively

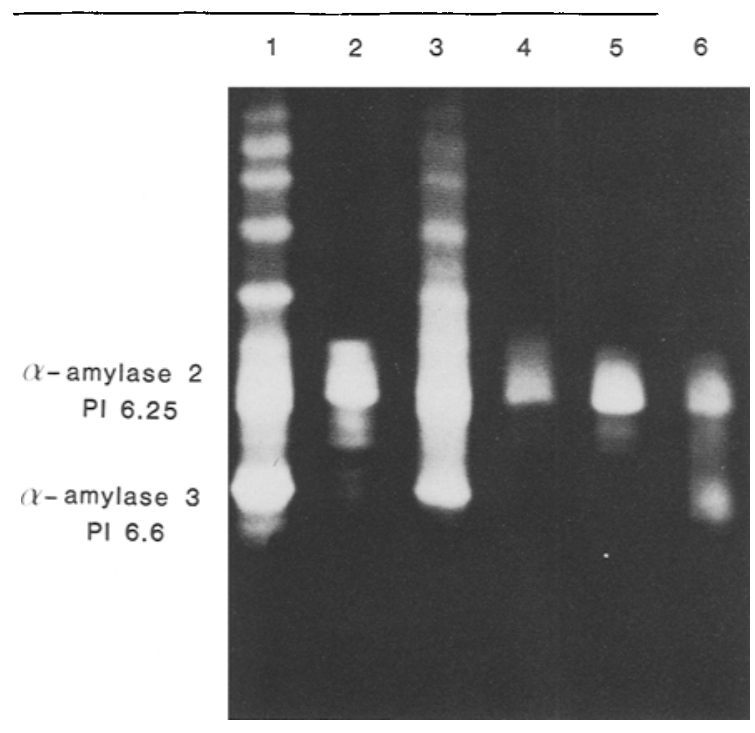

Figure 7. Effect of the inhibitor and heat treatment on the isoelectric focusing patterns of $\alpha$-amylase 2 and extracts of green and kilned barley malts.

Gels were stained for amylase activity after isoelectric focusing. Lanes: 1) green malt extract; 2 ) as 1 , heat-treated; 3) kilned malt extract; 4 ) as 3 , heat-treated; 5) $2 \mu \mathrm{g} x$-amylase 2 ; 6 ) as 5 , with $2 \mu \mathrm{g}$ inhibitor. 


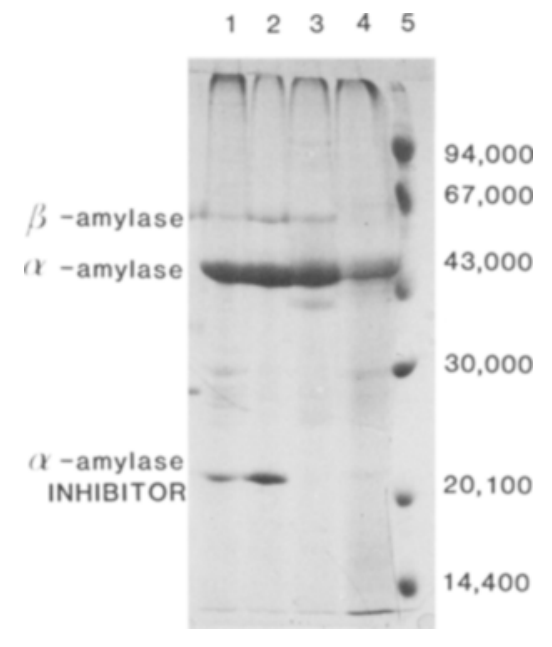

Figure 8. Proteins in glycogen precipitates of wheat, barley, sorghum and rye malt extracts.

Samples (approximately $60 \mu \mathrm{g}$ ) were compared by SDS-PAGE in a $15 \%$ gel.

Lanes: 1) wheat; 2) barley; 3) sorghum; 4) rye. Lane 5 is a molecular size standard mixture as in Figure 3.

synthesized during germination, at which time it apparently has only a passive function. It is, however, tempting to speculate that the inhibitor may serve a regulatory role during seed development by inhibiting endogenous $\alpha$-amylase activity during starch granule synthesis and/or that the inhibitor may delay starch degradation caused by premature sprouting.

SDS-PAGE of glycogen precipitates of wheat, barley, sorghum and rye malt extracts shows substantial amounts of a protein of the same molecular weight as the barley $\alpha$-amylase/subtilisin inhibitor in wheat, smaller amounts in rye and apparently none in sorghum (Figure 8 ). This evidence, combined with comparative data from isoelectric focusing of cereal grain subtilisin inhibitors by HEJGAARD (5), suggests that inhibitors similar to the barley $\alpha$-amylase/subtilisin inhibitor are present in other cereals, including wheat and rye.

The present discovery of relatively large amounts of an inhibitor of endogenous $\alpha$ amylase in barley malt and in barley (17) may be of interest to plant breeders and physiologists due to the importance of barley malt $\alpha$-amylase in the brewing industry. Of practical interest to the brewer is the finding that heat treating an extract of kilned malt completely removes the $\alpha$ amylase-inhibitor complex (Figure 7). This treatment corresponds to the final stages of the amylolytic rest during mashing. The data on infusion mash tun processes collected by HougH et al. (8), which showed that the optimal temperatures for starch conversion and $\alpha$-amylase activity were $65-68^{\circ} \mathrm{C}$ and $70^{\circ} \mathrm{C}$, respectively, suggest that optimal $\alpha$-amylase activity may only be obtained in mashing when the $\alpha$-amylase inhibitor is inactivated.

\section{CONCLUDING REMARKS}

This communication presents evidence to show that 1) an inhibitor of endogenous $\alpha$ amylase 2 exists in barley and barley malt, 2) the pattern of $\alpha$-amylase isozymes in germinated cereal seeds can be partially explained by the presence of $\alpha$-amylase-inhibitor complexes, and 3) inhibitory activity towards two entirely unrelated hydrolases is associated with a single, relatively small barley protein molecule.

\section{ACKNOWLEDGEMENTS}

The authors wish to thank Fil. Dr. LARS MUNCK for stimulating discussions and Drs. IB JONASSEN and GREGORY GIBBONS for suggestions during the chromatographic and electrophoretic experiments. The advice of Cand. Stat. L. SEJERSEN and Civ. Ing. K. JøRGENSEN with the kinetic analyses, the work of Civ. Ing. LARS HALLGREN and of BODIL CORNELIUSSEN with the amino acid analyses and the assistance of ANNETTE HANSEN and METTE Høנ in preparing the figures is greatly appreciated.

\section{REFERENCES}

1. BiETH, J.: Some kinetic consequences of the tight binding of protein-proteinase-inhibitors to proteolytic enzymes and their application to the determination of dissociation constants. Bayer-Symposium V "Proteinase Inhibitors", 463-469 (1974).

2. Buonocore, V., T. Petrucci \& V. Silano: Review: Wheat protein inhibitors of $\alpha$-amylase. Phytochem. 16, 811-820 (1977)

3. BRown, A.H.D. \& J.V. JACOBSEN: Genetic basis and natural variation of $x$-amylase isozymes in barley. Genet. Res. Camb. 40, 315-324 (1982)

4. Dygert, S., L.H. LI, D. Florida \& J.A. Thoma: 
Determination of reducing sugar with improved precision. Anal. Biochem. 13, 367-374 (1965)

5. HeJgaARD, J.: Isoelectric focusing of subtilisin inhibitors: Detection and partial characterization of cereal inhibitors of chymotrypsin and microbial proteases. Anal. Biochem. 116, 444449 (1981)

6. Hejgaard, J., I. Svendsen \& J. Mundy: Barley $\alpha$-amylase/subtilisin inhibitor. II. N-terminal amino acid sequence and homology with inhibitors of the soybean trypsin inhibitor (Kunitz) family. Carlsberg Res. Comm. 48, 9194 (1983)

7. HIRS, C.H.W.: Determination of cystine as cysteic acid. Meth. Enzymol. 11, 59-62 (1962)

8. Hough, J.S., D.E. Briggs \& R. STEvens: Malting and Brewing Science. Chapman and Hall, London (1971)

9. Koller, A. \& H. Neukon: Detection of oligogalacturonic acids by thin-layer chromatography. Biochim. Biophys. Acta. 83, 366367 (1969)

10. MaCGregor, A.W.\& D. Ballance: Quantitative determination of $\alpha$-amylase enzymes in germinated barley after separation by isoelectricfocusing. J. Inst. Brew. 86, 131-133 (1980)
11. MacGregor, A.W., D.E. La Berge \& W.O.S. MEREDITH: Separation of $x$ - and $\beta$-amylase enzymes from barley malt by ion-exchange chromatography. Cereal. Chem. 48, 490-498 (1971)

12. MUNDY, J.: Isolation and characterization of two immunologically distinct forms of $x$ amylase and a $\beta$-amylase from seeds of germinated Sorghum bicolor (L.) Moench. Carlsberg Res. Commun. 47, 263-274 (1982)

13. Neville, D.M. Jr: Molecular weight determinations of protein-dodecyl sulfate complexes in gel electrophoresis in a discontinuous buffer system. J. Biol. Chem. 246, 6328-6334 (1971)

14. Rodaway, S.J.: Composition of $\alpha$-amylase from aleurone layers of grains of Himalaya Barley. Phytochem. 17, 385-389 (1978)

15. Shivaraj, B. \& T.N. Pattabiraman: Characterization of an unusual $x$-amylase/ trypsin inhibitor from ragi (Eleusine coracana Gaertn.) Biochem J. 193, 29-36 (1981)

16. Silvanovitch, M.P. \& R.D. Hill: Affinity chromatography of cereal $x$-amylase. Anal. Biochem. 73, 430-433 (1976)

17. Yoshikawa, M., T. Iwasaki, M. Fuji \& M. OOGAKI: Isolation and some properties of a subtilisin inhibitor from barley. J. Biochem. 79, 765-773 (1976) 